\title{
Black, White and Blue: Pregnancy and Unsettled Binaries in The Masque of Blackness (1605)
}

\begin{abstract}
This article examines the construction of national and racial identities within Ben Jonson's and Inigo Jones's Masque of Blackness against the backdrop of King James' investment in creating a 'British' union at the start of his reign. The article re-examines the blackface performance of the Queen and her ladies in the contexts of the Queen's and Inigo Jones' European connections, the Queen's reputation as 'wilful', and her pregnant body's ability to evoke widespread cultural beliefs about the maternal imagination's power to determine a child's racial make-up. We argue that the masque's striking use of blue-face along with black and white-face reveals a deep investment in Britain's ancient customs which stands in tension with Blackness' showcasing of foreign bodies, technologies, and cultural reference points. By demonstrating the significance of understanding Queen Anna's pregnancy and her 'wilful' personality within the context of early modern humoral theory, moreover, we develop existing discussions of the humoral theory that underpins the masque's representation of racial identities. We suggest that the Queen's pregnant performance in blackface, by reminding the viewer that her maternal mind could 'will' the racial identity of royal progeny into being, had the power to unsettle King James I's white male nationalist supremacy in the very act of celebrating it before their new English court and its foreign guests.
\end{abstract}

Keywords: masque, blackface, body paint, performance, set design, Queen Anna of Denmark, Ben Jonson, Inigo Jones, pregnancy.

\section{The Masque of Blackness: Inventing, Personating and Designing British National Identity}

Ben Jonson and Inigo Jones' The Masque of Blackness, the second masque commissioned by James I's Queen Consort, Anna of Denmark, was performed on Twelfth Night in the 1604-1605 Christmas revels season at the Jacobean court. The masque's performance in Whitehall's Banqueting Hall was immediately preceded by a performance of Shakespeare's Othello, and the two texts are often taught and studied side-by-side as two early Jacobean texts that

${ }^{*}$ University of Exeter. 
deal with racial alterity in ways that strikingly intersect with gender. Blackness, as Kim F. Hall (128) has influentially argued, "inaugurated a new era in the English court, which demonstrated a renewed fascination with racial and cultural difference and their entanglements with the evolving ideology of the state". Our purpose is to re-examine this masque, with its aristocratic female dancers' prominent use of blackface, without reference to its Shakespearean counterpart and without letting Jonson's dialogue crowd out the contributions of his collaborators. Instead, by focusing on the creative input of the masque's designer Inigo Jones and the Queen as its lead performer, we seek to understand this blackface performance in relation to Anna of Denmark's and Inigo Jones' European connections, the Queen's own reputation for wilfulness and resistance to her husband's decrees (Aasand; Iyengar; Barroll; McManus), and her pregnant body's ability to bring into play widespread cultural beliefs about the maternal imagination's power to determine a baby's racial make-up.

The court environment within which, less than two years after his arrival from Scotland, James was at pains to establish a new "British" national identity for himself and his subjects through the creation of mythologies of race was marked by a multiplicity of racial, cultural and national identities. Only a few months earlier, James had agreed a peace accord with Spain that heralded a period of increased mercantile activity throughout the Mediterranean (Jones 15 ); this was also a period of more general "growth of actual contact with Africans, Native Americans, and other ethnically different foreigners (which went much beyond anything seen previously in England)" (Hall 129). At the Jacobean court with its foreign ambassadors, visiting dignitaries (including, for that Christmas season, Anna's brother, the Duke of Holstein) and their entourages, Queen Anna was therefore one foreigner amongst many others. Brought up at the German-speaking court in Denmark and a Catholic convert (McManus 66, 92-96; Barroll 163-164; Murray), she had come down from her Scottish court speaking Scots, with English her fifth language (after Danish, Latin and French) (McManus 66) and Italian (which she studied with John Florio) her sixth. Having "moved between courts, bringing with her the influences and material traces of her previous culture", as Clare McManus (62) points out, the Queen was ambivalently poised between her new role as the female figurehead of the "British" body politic and her roots and continued interest in continental European court cultures.

In the genre of the court masque, in which aristocratic participants danced but did not speak, the Queen's foreign accent and descent are reimagined in terms of visible racial alterity through her and her ladies' application of blackface. The Masque of Blackness engages in a complex reconfiguration of the Scottish King and his Danish Queen in relation to their new composite realm, positing the King as quintessentially "British" (rather than either Scottish or 
English) and his foreign Queen and her ladies as drawn to him by a deep-seated desire for racial assimilation. At first sight, the founding mythology at the heart of the masque simply consists in suggesting the natural superiority of James as the "SVNNE" ruling over "BRITANIA" (B3V), which is surrounded by the overdeterminedly white "Snowy cliffe" of "Albion the fayre" (B3r). It is to him that twelve nymphs, the daughters of the river Niger, who are played by the Queen and her ladies, have travelled from "AEthiopia, ... the blackeft nation of the world" (A3v), through "Blacke Mauritania", "Swarth Lufitania" and "Rich Aquitania" (B2v). The masque's conceit is to suggest that the "light fcientiall" shed by the sun-king is "of force / To blanche an ÆTHIOPE and reuiue a Cor's" (B3v) and will confer on the nymphs the longed-for white beauty which is praised by poets. The masque famously ends without visualising this transformation from black to white, so that, as Sujata Iyengar (85) explains, "[t]he ladies end Blackness in the full glory of their make-up, resolutely unbleached by the rays of James' sun."

Jonson's masque script, with its fleeting allusion to the "swarth" colouring of the inhabitants of Lusitania (now southwest Spain and southern Portugal), therefore seems to acknowledge early modern "geohumoural" thinking which, as we will see, primarily attributed differences in skin colour to climatic differences in heat and to environmental influences (Floyd-Wilson English Ethnicity 4; Andrea 272) only to resolve itself in a binary opposition of black and white skin tones. The masque ostensibly grafts this binary opposition of white and black onto gendered positions in which the "light fcientiall" and whiteness of an immovable, insular Britain and its temperate sun is gendered male, whereas the fluidity, blackness and wilfulness of the river nymphs, who do not heed their father's reasoning, are gendered female. And those gendered positions, in turn, match the respective authorial positions of cerebral, steady Jonson as the writer of the masque and physical, wilful Queen Anna as its lead performer: keen to distance himself from "her Maiefties will, to haue [the lady masquers] Black-mores at firft" (A3v), Jonson distinguishes between the Queen's wish to "perfonate" her character in black-face and his own "inuention" of the evening's entertainment (title page and C2r; A3v).

Bridging the gap between Jonsonian invention and royal personation, however, are the masque's ostentatiously European performance technologies, which are the brainchild of architect, stage engineer and designer Inigo Jones. Jones brought to the collaboration not just his experience of working for Anna's brother, King Christian IV of Denmark, but also expertise in the cutting-edge stage technologies developed in what is now northern Italy. In particular, he was familiar with the designs and innovative stage machinery that had stunned guests in Florence at the pageants in honour of the wedding of the French Princess Christine of Lorraine and the Grand Duke Ferdinando de Medici in 1589, as well 
as of the perspective arrangement of audience seating and stage designs in Andrea Palladio's Teatro Olimpico (Vicenza) and Vincenzo Scamozzi's Teatro all'anticha (Sabbioneta) (Baugh 24-27). Jonson's acknowledgement of Jones' creative contribution to Blackness carefully positions his collaborator between the poles of invention/design and personation/action when, to wind up his convoluted introductory description of the scenic design, he writes: "So much for the bodily part. Which was of Maifter YNIGO IONES his defigne, and act" $(\mathrm{A} 4 \mathrm{v})$. The dismissiveness with which Jonson treats Jones' input here suggests that it might be worth paying closer attention to Jones' "design, and act", since it evidently was the means whereby Jonson's invention was reconciled with the Queen's silent but wilful performance of blackness.

Accordingly, the first part of this essay examines theatre historical evidence in order to explore "the bodily part" of the masque's physical staging of power relations and its deployment of white, blue and black-face cosmetics. Our analysis of the masque's "bodily part" reveals the extent to which through a spectacle that was coded as pan-European in some respects and insularly British in others, the hierarchical oppositions of Jonson's plot were challenged and the myth-making that informed geohumoural racial theories was made visible. In the second part of the essay, we turn our attention to how the Queen "perfonated" (C2r) the blackface role of the nymph Euphoris. For this, we investigate early modern constructions of pregnancy and layer onto our exploration of the masque's visual effects a focus on the body of the Queen who was six months pregnant with her daughter Mary at the time of the performance. Anna of Denmark's personation of Niger's daughter and her wilful fancy to do so in blackface, we suggest, puts further pressure both on the central conceit of white masculine dominance and on the binary opposition of black and white. While the Queen's blackface performance reveals her own investment in the masque's celebration of white beauty and Britain's national supremacy, it also blurs some of the racial and gendered distinctions on which this assertion of supremacy depended. Rather than simply enshrine the superiority of the white British King over the black African river nymphs, we argue that the masque, not least through Jonson's suggestion that what spurred the nymphs' desire for whiteness was the poets' praise of other empires' "painted Beauties" (B2r), also exposes the extent to which normative British whiteness itself was a myth. The Queen, who appropriates blackness for her own purposes, demonstrates her own promotion of hierarchies that depend on skin colour. However, the international spectacle that was created, and which drew attention to the Queen's 'wilful' influence at court, also decentres James' Britain and unsettles the myth-making that places black and white in opposition. In an environment in which people from different racial and cultural groups rub shoulders, binary oppositions break down along with the familiar colonialist narrative that sees the feminised "other" as subordinate to masculine whiteness (Hall 133-134; Habib 157). 


\section{The "Bodily Part": European Technologies and the Celebration of British Identity}

Piecing together "the bodily part" of the masque's "action" involves marrying up Jonson's description of the designs in the published text with Jones' surviving costume designs, the records of the Pipe Office Works Accounts, and the letters written by courtiers present at the performance. The Works Accounts reveal the extent to which Jones' expertise in Northern Italian theatre design had an impact on this masque. Not only do they record that the "roofe overheade" was painted "with cloudes and other devices" in the manner of Palladio's Teatro Olimpico, but they specify that Whitehall's Banqueting House was to be equipped, on this occasion, with a "greate stage ... xlty [40] foote square and iiior [4] foote in heighte with wheles to go on". That stage was to be matched by "an other stage a greate halpace" high, which was to be surrounded by seating on "degrees ... for people to sitt on" (anon.). The masque, therefore, took place on and between two competing stages: one, the customary stationary stage for the King's throne at one end of the room; the other the Italian-inspired innovation of a $3.71 \mathrm{~m}^{2}$ raised stage with perspective design that could accommodate at least thirty-two performers, arranged "feated, one aboue another: fo that they were all feene" (A4r), and that could roll forwards towards the King at the start of the performance.

This forward thrust of the movable stage corresponds to the point when Jonson's script calls for the "Landtschape" of small woods painted onto a curtain to fall. The novelty of the concept of a painted landscape is signalled in Jonson's awkward Dutch spelling: European exoticism imbues even the language Jonson uses to describe Jones' spectacle (Lindley 216, note 20). The falling curtain revealed an "artificiall Sea" which " $\mathrm{ho}[\mathrm{t}]$ forth, as if it flowed to the land, raifed with waues, which seemed to mooue" (A3v). At its centre was a large and brightly lit scallop shell on which the twelve lady masquers were thrust towards the King and the assembled court as if "ris[ing] with the billow" (A4r). Once the ladies had descended from their stage and performed their first showcase "Fingle Daunce" on the hall floor at the foot of the King's throne, a tenor, to a score written by Antonio Ferrabosco II (Schmalenberger), urged them to "Come away", prompting the ladies to "make choice of their Men" (B4v).

One of these men, we know thanks to a letter by Sir Dudley Carleton ("Masque of Blackness 12"), was the Spanish Ambassador, who had been invited in a private capacity and was therefore there "disguised". The Ambassador was first "taken owt to dance and footed it ... like a lusty old gallant with his cuntrywoeman". He then initiated another dance and "tooke owt the Queen", placing himself at the centre of the masque's spectacle by selecting his royal dance partner. In the middle of the evening's entertainment, therefore, there was what Carleton, in another letter ("Masque of Blackness 6"), describes as a spectacle riven with strangeness: he is "sory that strangers should see owr 
court so strangely disguised". In Carleton's eyes, both the foreign dignitaries participating in the masque and the masquers in blackface provided a "strange" spectacle as they danced a succession of slower, traditional English measures (Ravelhofer 41) and faster-paced Continental "coranto's" or "courantes", for which there was "a fashionable craze" at the time of Blackness' performance (Pulver 100; Barroll 87). For the foreign guests, on the other hand, Blackness' corantos had, as Barbara Ravelhofer points out, "a high recognition potential" as they "suddenly heard or saw something they recognized from their home country" which encouraged "a common identity shared by performers, patrons, and audience" (73). In the masque's penultimate phase, another song, this time sung by "two trebles" (presumably the "paire of Sea-Maides, for fong" (A3v) who were seated behind six Tritons), called the ladies back to the giant sea shell on which they had entered. The entire set then "went out" as the artificial sea ebbed away from the King's throne on his static stage, to the tune of a final song about the waning of the moon that controlled this artificial tide.

No wonder, given the multiplicity of musical, technological and visual borrowings from northern Italian, French, and Dutch practices, as well as the flattering involvement of the Spanish Ambassador, that James' foreign guests, rather than put out by the masque's heavy-handed celebration of Britain's insular superiority as "A World, diuided from the world" (B3v), were delighted by the entertainment that visually signalled cultural connection rather than political division. Ottaviano Lotti, secretary to the Florentine ambassador, reported that the "Queen's masque was performed" and was "more magnificent" and of rarer invention than the masque performed for Susan de Vere's wedding a few weeks earlier, and that it was "staged in a larger room, very richly decorated." He also noted that new engines ("nuovi apparati") had been built for these "[t]wo superb masques". ${ }^{1}$ For his part, Nicolo Molin, the Venetian ambassador, reported that "the Masque...was very beautiful and sumptuous", and even M. de Beaumont, the French ambassador who had felt slighted by the attention given to his rivals and therefore stayed away claiming illness, described the event second-hand as "this superb ballet" ("ce superbe ballet") (qtd in. Barroll 103).

Jonson's description of Jones' design makes it clear that the most important thing governing this remarkably pan-European spectacle was the King's eye-line from the vantage-point of his elevated throne. That is the point of Jonson's specification:

${ }^{1}$ Orrell and the Cambridge Ben Jonson edition both translate Lotti's "nuovi apparati" as "new scenes", but the proximity with "bellissimi teatri" ("extremely beautiful theatres") makes it more likely that he is commenting on the novel stage engines inspired by the Florentine wedding which English observers described variously as "secrett ingines" (Vincent) or the masque's "great engine ... which had motion" (Carleton, "Masque of Blackness 12"). 
Thefe thus prefented, the Scene behind, feemed a valt Sea ... from the termination, or horizon of which (being the leuell of the State, which as placed in the vpper end of the Hall) was drawne, by the lines of Profpectiue, the whole worke fhooting downewards, from the eye; which decorum made it more confpicuous, and caught the eye a far of with a wandring beauty. (A4v)

The whole masque, it appears, observed "decorum" by being arranged to suit the King's sightline in the manner of northern Italy's Palladian perspectival theatres, putting him in total control of the perspective and at a level with its vanishing point. As the "greater Light, / Who formes all beauty, with his fight" (B2v), in fact, the King was not only given command over the perspective, but over the beauty of the masque and masquers altogether. James I was literally put in the position he had warned his son Henry about in Basilikon Doron, where he described how "a King is as one fet on a skaffold, whofe fmalleft actions \& gestures al the people gazingly do behold" (R1r). Jones' perspectival set-up and Jonson's poetic conceit make of King James I both the creator of the masque which "Thoot[s] downewards" (A4v) from his eye and its spectacular focal point in his own right as the stage is "feene to fhoot forth" (A3v) towards him, with "light" (B2v) referring both to his seeing and his being seen in relation to the spectacle and as an integral part of it and its power to shape beauty.

The King's positioning as both subject and object of the gaze becomes important at the point of the masque's great discovery of an alternative vantage point that rivalled that of the King and that, quite literally, outshone it:

At this, the Moone was difcouered in the vpper part of the houfe, triumphant in a Siluer throne, made in figure of a Pyramis. Her garments White, and Siluer, the drefling of her head antique; \& crownd with a Luminarie, or Sphere of light: which ftriking on the clouds, and heightned with Siluer, reflected as natural clouds do by the fplendor of the Moone. The Heauen, about her, was vaulted with blew filke, and fet with Starres of Siluer which had in them their feuerall lights burning. (B3r)

Positioned in the upper part of the house close to the ceiling vaulted with blue silk and silver stars, the moon's silver throne was placed higher than the King's state, so that the moon dominated, in her "Pplendor", the entire hall as she returned the King's "fight". 2 Played by a professional male performer trained to perform such a speaking part, the unambiguous femininity of this moon (in line with playhouse convention) was signified both through gendered costume and

2 Even if the "upper part of the house" were to refer to the rear of the extremely crowded stage, it would still signal an elevation of the moon's pyramid throne higher than the King's state, given that his throne was at a level with the stage with his eyeline at the level of the vanishing point. 
white face-paint (Karim-Cooper "This Alters Not", 144). The emphatic silverlaced whiteness of the moon, whom both Jonson's main text and his marginal annotations identify as "Fthiopia", flies in the face of Jonson's association of "Æthiopia", in his general description of the masque, with being "the blackeft nation of the world" (A3v). ${ }^{3}$ The set-up establishes this blue-clad "female" figure reuniting opposite racial signifiers as a rival creative force to that of Albion's King, capable of governing the ebb and flow of the masque and to splendidly outshine him with her silver-and-white garments and the sphere of light crowning her antique head-dress. It is surely no coincidence that, as Æthiopia reveals in her final address to the masquers ( $\mathrm{C} 1 \mathrm{v}$; see also Iyengar 85$)$, that it is by the "glorious light" of the full moon rather than "the beames of yond' bright Sunne"-an implicit deictic stage direction that is likely to have prompted a gesture pointing at the King-that the Daughters of Niger are to wash in rosemary dew in order to attain "perfection."

While the moon was thus associated with glorious whiteness and silver against a blue backdrop, on the scene below her, blue was by far the most dominant colour, with a total of thirteen characters in blue-face, at least another six in blue wigs, and further blue and sea-green-accented costumes against the blue backdrop of the seascape with its presumably blue sea-monsters. The six Tritons' half-human, half-fish nature is signalled in part through the blue colour of their hair "as pertaking of the Sea-colour" (A3v). Oceanus' identity as the Atlantic Ocean is indicated through "the colour of his flesh, blew; and shadowed with a robe of Sea-greene", and whereas his body is "presented in a humane forme", his grey and horned head features a "beard of the like mixt colour" of blue and sea-green (A4r). Jonson notes the "Sea-greene" tint (A4v), with interwoven gold and silver, of the skirts worn by the twelve Oceaniae, the women masquers who acted as torchbearers to Niger's daughters and who perched on top of "fixe huge Sea-monfters" (A4r), but he does not specify their skin colour. That they, too, were wearing blue-face, however, is evident from Inigo Jones' watercolour of "an Oceania as a torchbearer" (Chatsworth, Devonshire Collection) in which he colours her unvizarded face and hair blue, with what appear to be long blue sleeves or gloves to cover her arms and hands (Daye 250). Blue skin (both painted and prosthetic), sea-green fabrics, fishtails and sea-grass garlands are evidently deployed here as signifiers of the elemental nature of these creatures of the ocean.

3 Strikingly, both Vecellio's etching of an "Aethiopian Virgin" which Jones drew on for the costume of the Daughter of Niger (Orgel and Strong 96) and his own drawing of "Candace" (Chatsworth, Devonshire Collection), who is described as the "Pride of Aethiopia' in The Masque of Queens (1609), depict light-skinned women. They thus participate in the paradoxical combination of black and white features which Ania Loomba (8-10) finds in early modern "black bride" narratives based on Jeremiah $13: 23$. 
The blue ocean creatures, combined with the blue silk of the vaulted heavens above the moon, provide the backdrop to the protagonists of the masque: the Queen and her eleven courtly companions. As "Nymphs, Negro's; and the daughters of NIGER" (A4r), they wore cosmetic blackface, with their arms also painted black up to their elbows. This detail can be seen in Jones' watercolour design for the "Daughter of Niger"; it is further confirmed by two English eyewitnesses, whose accounts reveal the extent to which this display of painted skin was experienced as noteworthy. Vincent writes of how the ladies were "all paynted like Blackamores face and neck bare", while Carleton is more frankly scandalised about how the lady masquers' "faces and armes up to [the] elbowes were painted black, [which] was disguise sufficient for they were hard to be knowne, but it became [them] nothing so well as theyr read and white" ("Masque of Blackness 12"; see also "Masque of Blackness 6"). Carleton's cosmetics-induced racial anxiety extends to his concern for the cleanliness of the Spanish ambassador, who, when he danced with the Queen, "forgot not to kiss her hand, though there was danger it would haue left a marke on his lips" ("Masque of Blackness 12"). Of course, if Farah Karim-Cooper ("This Alters Not" 146) is correct in her suggestion that blackface performers in the early modern period sealed cosmetic pigments with an egg glaze, which would have had the added benefit of making their skin shimmer in the torchlight, then Carleton need not have been concerned about any potential smudging, however much he was disturbed by the various forms of strangeness at play in this interaction.

While at first sight the contrast between the blue-face of the ocean creatures, the black-face of the principal masquers and the white-face of the moon above might seem absolute, there are also several indications that blue and black were not so much opposed as interconnected colours that also bore a historical relationship with the "painted Beauties" so envied by Niger's nymphs. In fact, the costumes of Niger and his daughters integrated strong accents of blue that marked them, too, as river creatures: while "in forme and colour of an Aethiope", with "curled" hair and "rare beard", Niger is "Thadowed with a blew, and bright mantle" (A4r). Black and blue also combine in Jones' design for the Daughter of Niger (Chatsworth, Devonshire Collection), which was furthermore gender-bending in its inclusion of masculine buskins. If Ravelhofer (177) is correct in her interpretation of Vincent's reference to the "Barbaresque mantells to ye halfe legge, having buskins all to be sett w[i]th iewells", the costume might also have struck this viewer for its indebtedness to "French and Italian theatrical practice". Tellingly, Jonson describes that costume as being in "the colours, Azure, and Siluer ... interlaced with ropes of ... the molt choife and orient Pearle; beft fetting of from the black" (A4v). Hence, the overall stage image, in the flickering light of the Oceaniae's torches, was of azure bodies in dark green juxtaposed with the shimmering of black arms and 
faces in azure with accents of white created by the pearls, uniting them in an aesthetic whole.

Moreover, the actual face and body paints used by the blue torchbearers and the black masquers may have been based in the same natural blue dye, woad (Ravelhofer 173), and have therefore appeared, in the flickering light of the torches, as different shades of blue-black. ${ }^{4}$ That would certainly explain why Carleton ("Masque of Blackness 12") misidentifies the Oceaniae, who are blue in Jones' design, as "moores" who are distinct from "owr Lady-Moores" only by virtue of their inferior ranks as "a wayting gentlewoeman or some baggage". Woad, as Jonson's erstwhile schoolmaster William Camden points out in his discussion of "The Maners and Customes of the [ancient] Britans", was the body paint used by "the women of Britaine, as well married wives as their young daughters, [to] anoint and die their bodies all over; resembling by that tincture the colour of Aethiopians, in which maner they use at solemne feasts and sacrifices to goe all naked". This custom, Camden speculates in his chapter on "Britaine", may have been to create "a beautifull shew".

In his etymological discussion of "The Name of Britaine", furthermore, Camden suggests that the very name of "Britannia" is a compound of "brith", a word that denoted "painted, depainted, died, and coloured" and the suffix "-tania", which he notes (in a manner that suggests that Jonson remembered that section in Camden's text when he traced the travels of the nymphs ${ }^{6}$ ) also appears in the names of "Mauritania, Lusitania, and Aquitania." The very identity of the ancient Britons was therefore connected to their women's "depainted bodies", which were put on display for festivities. It seems, as Philippa Berry and Jayne Elisabeth Archer have argued, that in using Camden's Britannia as a source and

4 Virginia Mason Vaughan (67) suggests that the cosmetic used was "black grease"; Karim-Cooper follows Dympna Callaghan in suggesting the use of a soot-based solution ("This Alters Not" 146). Most recently, Morwenna Carr (79) has cited Nicholas Hilliard's recipe for a paint based on burnt ivory and gum and also suggested that the pigments used by theatre professionals were "made of charcoal, lampblack, coal, and cork added to bases of animal fats, grease, tallow, water, and egg white."

5 Even if the Oceaniae were painted in woad and the Daughters of Niger in a soot-based solution (see note 4 above), candlelit performances at the Sam Wanamaker Playhouse show that the colour distinctions between black and dark blue can blur sufficiently in low light to explain Carleton's inability to spot the difference.

6 Floyd-Wilson ("Temperature" 194) discusses the obviousness of "Jonson's debt to Camden's text" but rather than read the allusion to the painted beauties of other Empires as referring to English ladies as the descendants of the ancient Britons, which is the reading we propose, she understands the phrase as referring to the lady masquers who perform the dual roles of "Aethiopian nymphs and ancient British wives and virgins". In English Ethnicity (122-123), furthermore, Floyd-Wilson links woad paint specifically to Picts in a reading of Camden and Pliny that sees the dye as referencing specifically Scottish and Egyptian, rather than "British" identities. 
reference point, Jonson was deliberately "excavating and redefining 'native forms' and "native manners" so as to refresh the self-representation of the English Court at the dawn of James I's "new Britain" (119, 125). Ravelhofer additionally points out that by the time Milton wrote Comus (1634), in which he hails the "blue-haired deities" that inhabit "this isle", blue was associated with British identity in masque iconography (174). This antiquarian concern with British roots accords with Æthiopia's praise of the "ancient dignitie, and ftile" of "BRITANIA, this bleft Ifle" in the masque (B3V): Blackness is as deeply invested in tapping into Britain's ancient customs as it is in exploding the very insularity it extols through its showcasing of foreign bodies, technologies and cultural reference points. Hence, when Jonson's Niger describes how his daughters were stirred to envy by hearing poets sing of "The painted Beauties, other Empires fprung" (B2r), this is a three-pronged reference. At one level, Iyengar is certainly right to see in it "a theatrical in-joke that seems to equate blackness with unpainted or natural beauty, whiteness with artifice" (84). Beyond that, it invokes the "read and white" cosmetics normally worn by Queen Anna and her ladies, whose absence Carleton regrets on this occasion ("Masque of Blackness 12 ") and which are themselves a response to the extolling of red-and-white beauty in visual art and Petrarchan poetry (Karim-Cooper, Cosmetics 10-13). And finally, it points towards the blue-black body paint historically associated with British women at festivities and worn on this occasion by at least one half of the masque's female performers.

Via the prominent use of blue body paint in the masque and Camden's antiquarian unearthing of ancient customs and etymologies in Britannia, Blackness thus established a connection between the "Æthiopians", blue woad dye, and the ancient British "painted Beauties" so envied by Niger's daughters. Through Jones' fusion of Italianate stage technologies, Dutch landscapes, Franco-Italian dance styles and archetypally "British" dyes and its showcasing of the Danish-Scottish-English Queen, the "bodily part" of this "strange" masque about Britain's supposed white male supremacy highlighted the indebtedness of this Jacobean spectacle to cutting-edge Continental stagecraft. Moreover, Jones' blue-black colour palette blurred absolute distinctions between sea-creatures, the river Niger, and the nymphs that are his offspring, just as through his relative positioning of the King and the moon, Jones upended the power relations between the male and female poles of Jonson's masque text. The masque's costumes and cosmetics reminded its spectators that the women personated by the masquers were not so much human as mythological creatures who bodied forth the colours of their natural environments: the blue of the sea and river or the blackness of Africa's fertile soil. If climate and environment had an impact on racial make-up, as geohumoural theories stipulated, the colour scheme of Jones" "design, and act" pushed such mythologizing to absurdity in its presentation of blue sea-creatures and thereby destabilised all absolute skin 
colour distinctions and climatological explanations of racial difference. In a masque in which "whiteness" itself was associated with being "painted", and the only white presence other than the King on his separate throne was a single cross-dressed male performer in white-face, "blackness" was but one colour in a spectrum of cosmetic skin tones that are remarkable not for their binary opposition but, ultimately, for their lack of distinction and fixity.

\section{The Queen's Wilful Body: "Personating” Maternal Fantasies of Blackness and Whiteness}

It is against the backdrop of the masque's visual destabilisation of absolute opposition between black and white skin tones, female and male creative forces, "strange" and "British" people and stagecraft, and its engagement with geohumoural explanations for racial difference that we now return to Jonson's pointed parenthetical remark that it was "her Maiefties will, to haue [the lady masquers] Black-mores" (A3v). The use of blackface within Masque of Blackness seems bound, in Jonson's comment, to the Queen's assertion of "will" over the entertainment, demonstrating her concern for, and influence over, her own performance within the masque to which she leant her "authoritie, and grace" (A3r). Given that the Queen was six months pregnant at the time of the performance, this notion of the Queen's wilfulness takes on particular significance in relation to cultural ideas about maternal "wilfulness". As we will argue, the Queen's use of blackface while pregnant has multiple implications that suggest the degree to which the Queen's influence over the masque-her "will"-was visible in its performance. We will show how in itself, the Queen's involvement in the masque already indicates a wilful disregard of medical advice that cautioned against the physical exertion of dancing and warned against exciting the expectant mother's imagination, or "phanfie" (Sharp 124). At the same time, Anna's determination to appear in blackface also suggests her exploitation of medical advice regarding the way a pregnant woman's will/"phanfie" needed to be heeded for the wellbeing of the baby. Moreover, the pregnant Queen's blackface performance offered a visual cue for guests to recall stories about "Ethiopian" mothers, where the power of maternal thought was understood to determine the racial make-up of a baby. As such, the pregnant Queen's blackface performance highlighted a form of maternal wilfulness that frustrates a strict oppositional position between masculine "whiteness" and feminine "blackness" within the masque even more intrinsically than do Jones' design choices.

The significance of the Queen's pregnancy has recently been recognised by Sara Thiel, who uses biographical detail to trace how "Anna wielded her reproductive body as a weapon in Stuart court politics" (211), deploying it "as 
a bargaining chip" (216) through her performance in The Masque of Blackness. However, how Queen Anna's contribution to the masque can be understood as a demonstration of her specifically maternal "will" requires fuller exploration of what it may have meant to view Anna's painted pregnant body within the context of early modern ideas about generation. This is because modern generative theories did not yet consider heredity as "the transmission of characters and disposition in the process of organic reproduction" (Müller and Rheinberger 3). Instead, theories of generation were an amalgamation of Classical models, whereby humoral dispositions (dependent on properties of heat and moisture) from the father's seed, the mother's seed and uterine blood influenced a child's physicality. Properties of the physical environment, including climate, sources of nourishment, the sights and passions encountered, all influenced parents, who passed on those humours in their generative materials - and with them degrees of resemblance - to a child. In this humoral understanding of the relationship between the body and its surroundings, "Nature and nurture, or heredity and environment, were not yet seen as oppositions" (Müller and Rheinberger 4).

Bernadette Andrea and Floyd-Wilson have established the indebtedness of Blackness to a related humoral system of beliefs which Floyd-Wilson has dubbed the "geohumoural" (English Ethnicity 4) climate theory. This theory primarily attributed differences in skin colour to climatic differences in heat, resulting in a "spectrum of shades" (186) in order to track the journey of Niger's daughters across the world and through its different climes. Both critics note how geohumoural race theory stands in tension with the masque's fashioning of Albion's power, which relies on constructing absolute binary oppositions between the "whiteness" that the daughters seek and "blackness" that they reject (Floyd-Wilson "Temperature, Temperance" 186), so that, as Andrea (272) observes, the masque's "climate theory" is ultimately "ambivalent" in its formulation of Albion's "whitening" powers. Such ambivalence, Andrea contends, meant that the Queen's painted body "substantially unsettled the emerging dichotomy opposing blackness to femininity, beauty and chastity" (274). Yet while Floyd-Wilson and Andrea open up discussions about whiteness and blackness in relation to concepts of beauty and racial difference within the masque, they do not pay attention to Queen Anna's pregnancy, which would itself have been viewed within the context of the humoral doctrine they discuss. They therefore neglect the power of Anna's own pregnant body to rework the masque's narrative of transformation and its binaries of "black" and "white."

The Queen's pregnant body, we suggest, acted as a visual reminder of the persistent humoral model that connected mother, child and environment beyond the influence of fathers or kings. As the physician Nicholas Culpeper (156) observed, all of a mother's activities directly informed the humoral material with which she nourished her child: "your Child is nourifhed by 
your own blood, your blood is bred of your diet, rectified and marred by your exercife, idlenefs, sleep or watching, \&c.". How a mother engaged with her surroundings carried implications for the child in her womb, and, as Sara Read (133) has noted, pregnant bodies in early modern culture, whether real or performed, were often viewed in light of "a common thread founded in a distrust of woman and the secrets their bodies can conceal". Studies of early modern concerns surrounding the power of maternal imagination have especially focused upon the misogynistic framing of female generative powers, where female minds and bodies come under suspicion.

Understood as one way in which the pregnant body was open to influence from its environment, a woman's imagination could be understood as a threatening means by which humoral disturbance could affect the development of offspring. Levinus Lemnius, an influential medical writer of the period, warned that pregnant women should "fee nothing, that may move their mind to think "abfurdly" (14). The workings of the maternal imagination, and the mother's "absurd" response to a visual stimulus, could lead to a sudden disruption of generative humours, so that an alteration was immediately imposed upon the developing child. Common examples in early medical writings include children being born with harelips because the mother saw a hare, and birthmarks taking the shape of something the mother observed in a heightened state of emotion (Helkiah Crooke 300; Paré 978-979). As Marie-Hélène Huet's Monstrous Imagination has shown, hostility was often directed towards the maternal imagination, which threatened "usurpation of the father's role" in shaping progeny and-as suggested in the directions from Lemnius and Culpeper - cultivated a desire for management and containment of maternal bodies and minds (16).

Ideas that related the colour of a child's skin to the workings of the maternal imagination are recounted in numerous early modern writings (Sharp 118, 123). Ambroise Paré reproduces two particularly popular stories:

Queene of Aethiopia, by her husband Hidustes, being allo an Æthiope, had a daughter of a white complexion; becaufe in the embraces of her husband, by which the proved with childe, the earnestly fixed her eye and mind upon the picture of the faire Andromeda [...]

Hippocrates [...] freed a certain noble wo-man from fufpicion of adultery, who being white her felfe, and her husband alfo white, brought forth a childe as blacke as an Æthiopian, because in copulation she ftrongly and continually had in her minde the picture of the Æthiope. (978)

These stories, in their emphasis on the intensity of the mother's thoughts at the moment of conception, are distinct from the maternal "surprise" narratives regarding harelips and birthmarks. These accounts of conception stress that the origins of "blackness" and "whiteness" depend on more than the humoral 
qualities of the seeds produced by parents because the nature of the mother's thought is key. The father's thoughts, perhaps more trusted than those of the mother, go unrepresented and - in its apparent absence of influence - appear less powerful. Moreover, while shocks and surprises regularly framed the female imagination as open to external influences beyond the woman's own control (reacting "abfurdly" to what is seen), depictions of the "black" mother, usually an Ethiopian Queen, who produces a "white" child, and the "white" mother who produces a "black" child, repeatedly identify an intent of thought, as the woman wilfully directs her attention onto a racially coded image.

These stories about maternal fantasies of "whiteness" and "blackness" notably act to limit the timeframe for maternal imagination to have an influence over a child, perhaps suggesting anxieties over miscegenation by focusing upon the act of generation, wherein maternal imagination allows for interracial sex itself to be denied. Laura Gowing has suggested, moreover, that these ideas could enable racist attitudes that indulge a fantasy by which "blackness can be imagined in and out of existence" (134), and while Gowing offers an example of such thinking in a contemporary account, the model for maternal imagination can be seen to show how blackness and whiteness can be imagined into and out of existence. Hall has observed that this imagining of "blackness" and "whiteness" in pregnancy narratives contributed to constructing a model of opposition that "others" blackness in contrast to whiteness, and this same binary modelling can be perceived in Blackness' plot of racial transformation. By having a child's skin colour be determined in the moment of conception, however, the child's skin (which does not yet exist) is not transformed in the same way proposed in the masque's narrative about transforming "black" to "white" skin; in utero, skin colour is formed out of this imagistic origin and the mother's assertion of "will." "Blackness" in these examples is identified with Ethiopia, but the accounts also suggest that geographical location-in contrast with the type of climate theory Floyd-Wilson and Andrea have explored in relation to Blackness - is not the humoral determinant of skin colour. Instead, as with the obstinately "Set[t]led thought" (B2v) of Niger's daughters, it is the mother's focused desires which, without requiring the aid of a Sun King, play the determining role in the child's pigmentation.

By being visibly pregnant and painted black in a masque whose tidal cycle is presided over by "\#thiopia," Queen Anna's performance in Blackness invokes these familiar narratives from medical and popular literature. Her intense preoccupation with the thought of appearing with her ladies in the guise of "Black-mores" was likely first expressed (and certainly realised in performance) after the moment of her child's conception. As a result, attendees at the masque probably would not have believed that the Queen's blackface performance would itself affect the racial identity of her developing baby. At the same time, the cultural associations of the performance act to remind viewers that all mothers (in line with early modern medical thinking) have the power to 
determine the colour of their child's skin when they conceive. The Queen's pregnant "blackface" appearance invokes less the ideas about maternal impressions that result from sudden, unexpected events, or material "staining" (Thiel 223) and more the focussed self-assertion of a Queen whose "personation" within the masque is associated with thoughts the mother-to-be "Itrongly and continually had in her minde" (Paré 978). Set within the context of the masque's overt recall of Æthiopia (as both the figure of the moon, and the location from where Niger's daughters have travelled), and of the masque's concern for the power of women's "Set[t]led thought" (B2v), the pregnant Queen's blackened body alludes to a maternal will in which the Queen's selfassertion clearly features. Drawing upon cultural associations that identified the power of maternal thought to determine the colour of a child's skin, the pregnant Queen's blackface performance in Blackness corresponds to what we already know about Anna's forthright character and realises a particularly powerful demonstration of the Queen's "will" in showcasing her wilful pregnant body.

It is therefore clear from early modern medical writings that all issues relating to the physicality of children, including skin colour, hinged upon an understanding of the mother's "will," or "phanfie" during pregnancy (Sharp 121; Read 141-144). Acknowledging the will/"phanfie" of a pregnant woman was, accordingly, taken seriously and understood as a part of safeguarding the wellbeing of a child. From recording a mother's food cravings to observing her ardent desires, medical writers recognised the connection between mother and child as an enabling as well as a destructive relationship. On the one hand, a mother who longed for "figs, or rofes, or fuch things" might promote physical changes, "moved by the phanfie", that would "imprint this likenefs from imagination" onto the child (Sharp 124). On the other hand, medical writers also "warned that unwholesome longings, if they were frustrated, could cause abortion or make 'foul impressions' on the child" (Gowing 128; Lemnius 16-18). Sara Read has shown, moreover, that mothers could take advantage of their position in perceiving the needs of their pregnant body: "women might have overstated their longings in the expectation that their husbands would not want to risk the pregnancy by not fulfilling their every whim" (136). Jane Sharp observed that pregnant women "defire to fomething not fit to eat nor drink, as fome women with child have longed to bite off a piece of their Husbands Buttocks" (103). Presumably most husbands' buttocks remained intact, but medical writers suggested that the cravings and "phanfie" (Sharp 124) of pregnant women should be accommodated where possible. ${ }^{7}$

Early modern observers depended on mothers to articulate their own perception of their pregnancy, identifying key moments of development, as in

${ }^{7}$ Similar observations can be found in other medical writings; see Jaques Guillemeau (26) and Lemnius $(14,285)$. 
the perception and announcement of the child's "quickening" (perceived movement within the womb) and in articulating their own needs for a healthy pregnancy (Gowing 122; Read). As Jakob Rüff notes in The Expert Midwife, the pregnant mother's desires should be taken into account and understood in relation to the condition of the developing child, whereby a "happy" mother made a "happy" child: "Before all things, let them be of a merry heart, let them not be wafted and pined with mourning and cares, let them give their endevour to moderat joyes and fports" (67). The child would enjoy and be "ftrengthen[ed]" by the mother's activities, so that entertainments designed according to a mother's desires would "cheare up the Infant" too (Rüff 67). Having her "will" might, then, be the best way for a mother to avoid dangerous passions that could endanger a child and even promote miscarriage.

Understood in light of early modern ideas about maternal thought, the prominence of Queen Anna's "will” in Blackness suggests Jonson's and King James' accommodation of the Queen's longings in pregnancy, or even a response to a more threatening ransoming of her influence over the child (Thiel). Leeds Barroll, who has observed more generally the Queen's "wilfulness" over the guardianship disputes for Prince Henry, records how the King and his advisors were used to accommodating the Queen's "will": "since the crux of the problem was the fixedness of Anna's will, apparently the solution, in the opinion of all involved parties, was to accede to this willbecause nothing else would work." (31-32). Following an incident in which James had to appease the Earl of Mar "in case [the Queen] continue in that wilfulness as she will not hear your credit" (qtd in Barroll 30), Lord Fyvie, a member of the Scottish Privy Council, felt pushed to offer advice to the King regarding the Queen's wilful personality. His letter similarly suggests a strategy of compliance in order to moderate the Queen's expressions of her will: "Her Majesty's passions could not be so well moderated or mitigated as by seconding, following, and obeying all her directions" (qtd. in Barroll 32). The "will" of the forthright Queen was no doubt even more apparent to those at court at a time when she was visibly pregnant.

Indeed, ahead of the performance of Blackness, Ottaviano Lotti seems to have found the Queen's plan to participate in the masque unusual because of her pregnancy: "even though she is several months pregnant", Lotti remarks, the Queen "has commanded a masque at which she will dance" (emphasis added). Lotti's account suggests both that the Queen's command is out of the ordinary but permitted, and that the surprising aspect of the pregnant Queen's involvement in the masque was her dancing. Early modern medical advice warned that pregnant women should avoid "vehement labour in running, leaping, and dauncing" as possible "causes of abortion or untimely birth" (Paré 921), and Lotti's implicit reservations about the Queen's involvement in the masque may relate to these concerns and his possible anticipation of the vigorous corantos she would be performing. Molin, however, observed 
the Christmas preparations in a different vein to that of Lotti, positioning the entertainments as part of the scheduled event in the Queen's progressing pregnancy: "Once these festivities are over, at Candlemas, the Queen will go to Greenwich and stay there till her child is born. Her pregnancy continues happily." For Molin, the Queen's involvement in the masque appears designed as her last public event before confinement, in line with a "happy" pregnancy that is going to plan. Part of that plan, for Molin, as for most commentators, involves understanding the masque as the Queen's event, which they attend, at least in part, according to her "will": "I knew that the Queen would like her masque to be seen". Therefore, it is clear that even the foreign attendees at the masque were alert to the Queen's pregnancy and saw the entertainment specifically as hers. Among the English observers, Vincent explicitly noted that the King would pay for the costly masque in order to "execute ye Queens fancye", using a word that echoes the medical descriptions of maternal longing.

The Queen's painted "black" body, then, seems to exhibit her imagistic power, by being evocative of a narrative about the intense power of the pregnant "Ethiopian" mother, and also through her demonstrable ability to have her "will" in the manner by which she can display her pregnancy in a blackface performance. Anna's black pregnant body, signposted further by symbols of fertility in her costuming (McManus 15), draws attention to the way that the proverbially impossible underscores the fashioning of both the King and Queen's representation in the masque: the ability to "blanch an Æthiope" is not only possessed by Albion's Sun-King, but it is also a power attributed to the maternal "will." From her elevated position in the masque, the moon, pointedly identified as "Fthiopia" and bound to early modern understanding of cycles at work within the female generative body, delivers the masque's infamous lines, but re-inscribes an uncertain gendering of transformative powers in her own visual and cultural signification. As we have seen, "Æthiopia," at once associated with "the blackeft nation of the world" (A3v) also appears in white, silver and blue, advocating but not requiring the "blanching" she promotes, and collapsing the binary between "whiteness" and "blackness" by signifying both.

Hence, the assured position of James' patriarchal power and the binary oppositions on which it relies become a point of repeated challenge in a masque where the female figures of both the Queen and the moon not only appear to possess the transformative powers ascribed to the King, but are associated with blackness and whiteness, masculinity and femininity at the same time. Models of binary opposition - whether in terms of race, nationhood, or gender-begin to appear as artificial as the black, white and blue make-up applied to the bodies of the performers in the masque, and are exploded through the Queen's body which signifies blackness and whiteness, fertile femininity and buskined masculinity, European and British identities all at once. Jonson, who on his title page stresses the importance of how the masque was "perfonated By the moft magnificent of Queenes ANNE Queene of great Britaine, \&c.”, is also tellingly unable to 
fully describe the Queen's performative contribution in relation to his own "invention" of the masque's words (just as his "\&c." limply gestures at her multiple national identities). In his concession, at the end of the script, that the masque "had that succefle in the nobility of performance; as nothing needes to the illuftration, but the memory by whome it was perfonated" (C2r), Jonson asks us to recall the "strange" and wilful Queen's pregnant performing body in recognising how The Masque of Blackness should be understood. In the context of a masque that is so deeply riven by contradictions, a conclusion which may look like the standard Jonsonian trope of ineffability whereby (as in his epigram 76 "On Lucy, Countess of Bedford") it is enough to name the object of his flattery to say all there is to say about them, reads ever more like his admission that his script, despite all its descriptive passages and marginalia, is unequal to the task of conveying the full meaning of the evening's entertainment. The paradoxes of the masque, this suggests, can be reconciled neither through the power or "light fcientiall" (B3v) of the King nor through the poet's attempt at citing his sources, explaining the "decorum" of Jones' perspective design, or describing the colour schemes of costumes and wigs. Instead, reconciliation is only possible through the strikingly indecorous performance of the Queen. There is no question of seeing her blacking-up, and the masque's framing of that act and of the blackness of Niger's daughters as something to be remedied by blanching, as anything but a celebration of the Queen's underlying white beauty and an implicit assertion of white supremacy. Nevertheless, the performance's repeated blurring of racial and gendered categories, and the ability of the Queen's pregnant performance in blackface to cue the viewers' awareness that her maternal mind can "will" the blackness and whiteness of royal progeny into being, also work to unsettle her husband's white male nationalist supremacy in the very act of celebrating it before James I's new English court and its foreign guests.

\section{WORKS CITED}

Aasand, Hardin. "To Blanch and Ethiop, and Revive a Corse': Queen Anne and The Masque of Blackness." Studies in English Literature, 1500-1900 32.2 (1992): 271-285.

Andrea, Bernadette. "Black Skin, The Queen's Masques: Africanist Ambivalence and Feminine Author(ity) in the Masques of "Blackness" and "Beauty."' English Literary Renaissance 29.2 (1999): 246-281.

Anon. "Masque of Blackness 4: Pipe Office, Works: Declared Accounts of Andrew Kerwyn, Paymaster of the Works." The Cambridge Edition of the Works of Ben Jonson Online. Ed. Martin Butler, David M. Bevington, Karen Britland, Ian Donaldson, David L. Gants, and Eugene Giddens. Cambridge: Cambridge University Press, 2014. http://universitypublishingonline.org/cambridge/benjonson/

Barroll, Leeds. Anna of Denmark, Queen of England: A Cultural Biography. Philadelphia: University of Pennsylvania Press, 2001. 
Baugh, Christopher. "“Devices of Wonder': Globalizing Technologies in the Process of Scenography." Scenography Expanded: An Introduction to Contemporary Performance Design. Ed. Joslin McKinney and Scott Palmer. London: Methuen, 2017. 23-38.

Berry, Philippa and Jayne Elisabeth Archer. "Reinventing the Matter of Britain: Undermining the State in Jacobean Masques." British Identities and English Renaissance Literature. Ed. David J. Baker and Willy Maley. Cambridge: CUP, 2002. 119-134.

Camden, William. Britannia (1607). Trans. Philemon Holland (1610). Ed. Dana F. Sutton. The University of California, Irvine, 2004. 3 March 2020. http://www.philological.bham.ac.uk/cambrit

Carleton, Dudley. "Masque of Blackness 6: Letter, Dudley Carleton to John Chamberlain, 7 Jan. 1605." The Cambridge Edition of the Works of Ben Jonson Online. Ed. Martin Butler, David M. Bevington, Karen Britland, Ian Donaldson, David L. Gants, and Eugene Giddens. Cambridge: Cambridge University Press, 2014. http://universitypublishingonline.org/cambridge/benjonson/ "Masque of Blackness 12: Letter from Sir Dudley Carleton to Ralph Winwood, January 1605." The Cambridge Edition of the Works of Ben Jonson Online. Ed. Martin Butler, David M. Bevington, Karen Britland, Ian Donaldson, David L. Gants, and Eugene Giddens. Cambridge: Cambridge University Press, 2014. http://universitypublishingonline.org/cambridge/benjonson/

Carr, Morwenna. "Material / Blackness: Race and Its Material Reconstructions on the Seventeenth-Century English Stage.” Early Theatre 20.1 (2017): 77-96.

Chamberlain, John. "Masque of Blackness 11: Letter from John Chamberlain to Ralph Winwood, 18 December 1604." The Cambridge Edition of the Works of Ben Jonson Online. Ed. Martin Butler, David M. Bevington, Karen Britland, Ian Donaldson, David L. Gants, and Eugene Giddens. Cambridge: Cambridge University Press, 2014. http://universitypublishingonline.org/cambridge/benjonson/

Culpeper, Nicholas. A Directory for Midvvives Or, a Guide for Women, in their Conception, Bearing, and Suckling their Children. London, Printed by Peter Cole, at the sign of the Printing-Press in Cornhil, near the Royal Exchange, 1651. ProQuest, https://search.proquest.com/docview/2264191396? accountid=10792

Daye, Anne. "Torchbearers in the English Masque.” Early Music 26.2 (1997): 246-262.

Edmonds, Thomas. "Masque of Blackness 13: Letter from Sir Thomas Edmonds to the Earl of Shrewsbury, 5 Dec. 1604." The Cambridge Edition of the Works of Ben Jonson Online. Ed. Martin Butler, David M. Bevington, Karen Britland, Ian Donaldson, David L. Gants, and Eugene Giddens. Cambridge: Cambridge University Press, 2014. http://universitypublishingonline.org/cambridge/benjonson/

Fissell, Mary. Vernacular Bodies: The Politics of Reproduction in Early Modern England. Oxford: Oxford University Press, 2004.

Floyd-Wilson, Mary. English Ethnicity in Early Modern Drama. Cambridge: Cambridge University Press, 2003.

"Temperature, Temperance, and Racial Difference in Ben Jonson's 'The Masque of Blackness'.” English Literary Renaissance 28.2 (1998): 183-209. 
Gordon, Donald James. "Poet and Architect: The Intellectual Setting of the Quarrel between Ben Jonson and Inigo Jones". The Renaissance Imagination: Essays and Lectures by D. J. Gordon. Ed. Stephen Orgel. Berkeley: University of California Press, 1980.

Gowing, Laura. Common Bodies: Women, Touch and Power in Seventeenth-Century England. London: Yale University Press, 2003.

Habib, Imtiaz. Shakespeare and Race: Postcolonial Praxis in the Early Modern Period. New York: University Press of America, 2000.

Hall, Kim F. Things of Darkness: Economies of Race and Gender in Early Modern England. Ithaca and London: Cornell University Press, 1995.

Huet, Marie-Hélène. Monstrous Imagination. London: Harvard University Press, 1993.

Iyengar, Sujata. Shades of Difference: Mythologies of Skin Color in Early Modern England. Philadelphia: University of Pennsylvania Press, 2005.

James I, King of England, Basilikon Dōron Devided into Three Bookes. Edinburgh, Printed by Robert Walde-graue printer to the Kings Maiestie, 1599. ProQuest, https://search.proquest.com/docview/2240861608? accountid=10792

Jones, J. R. Britain and Europe in the Seventeenth Century. London: Edward Arnold, 1966.

Jonson, Ben. "The Masque of Blackness (1608 quarto)". The Cambridge Edition of the Works of Ben Jonson Online. Ed. Martin Butler, David M. Bevington, Karen Britland, Ian Donaldson, David L. Gants, and Eugene Giddens. Cambridge: Cambridge University Press, 2014. http://universitypublishingonline.org/ cambridge/benjonson/

" "On Lucy, Countess of Bedford". Epigram 76 in Epigrams (1616). Ed. Colin Burrow. The Cambridge Edition of the Works of Ben Jonson Online. Ed. Martin Butler, David M. Bevington, Karen Britland, Ian Donaldson, David L. Gants, and Eugene Giddens. Cambridge: Cambridge University Press, 2014. http://universitypublishingonline.org/cambridge/benjonson/

Karim-Cooper, Farah. “This Alters Not Thy Beauty': Face-paint, Gender and Race in Richard Brome's 'The English Moor'.” Early Theatre 10.2 (2007), 140-149, p. 146.

Cosmetics in Shakespearean and Renaissance Drama. Edinburgh: Edinburgh UP, 2012.

Lemnius, Levinus. The secret miracles of nature. London, Printed by Jo. Streater, 1658. Proquest, https://search.proquest.com/docview/2240954411 ?accountid=10792

Lindley, David, ed. Court Masques: Jacobean and Caroline Entertainments, 1605-1640. Oxford and New York: Oxford University Press, 1995.

Lotti, Ottaviano. "Masque of Blackness 21: Dispatch, 20 January 1604/05 (10 January o.s.)." The Cambridge Edition of the Works of Ben Jonson Online. Ed. Martin Butler, David M. Bevington, Karen Britland, Ian Donaldson, David L. Gants, and Eugene Giddens. Cambridge: Cambridge University Press, 2014. http://universitypublishingonline.org/cambridge/benjonson/

McManus, Clare. Women on the Renaissance Stage: Anna of Denmark and Female Masquing in the Stuart Court (1590-1619). Manchester: Manchester University Press, 2002. 
Molin, Nicolo. "Masque of Blackness 16: Dispatch, 2 January 1605 (12 January 1604 o.s.)." The Cambridge Edition of the Works of Ben Jonson Online. Ed. Martin Butler, David M. Bevington, Karen Britland, Ian Donaldson, David L. Gants, and Eugene Giddens. Cambridge: Cambridge University Press, 2014. http://universitypublishingonline.org/cambridge/benjonson/

Müller-Wille, Staffan and Hans-Jörg Rheinberger. Heredity Produced: At the Crossroads of Biology, Politics and Culture, 1500-1870. Cambridge: MIT Press, 2007.

Orgel, Stephen and Roy Strong. Inigo Jones: The Theatre of the Stuart Court, vol. 1. London: Sotheby Parke Bernet, 1973.

Orrell, John. "The London Stage in the Florentine Correspondence, 1604-1618." Theatre Research International 3.3 (1978): 157-178.

Paré, Ambroise. The Works of the Famous Chirurgion Ambrose Parey. Trans. Thomas Johnson. London, printed by Thomas Cotes and R Young, 1634. ProQuest https://search.proquest.com/docview/2248535515? accountid=10792

Pulver, Jeffrey. "The Dances of Shakespeare's England." Sammelbände der Internationalen Musikgesellschaft 15 (1913): 99-102.

Read, Sara. "Pregnant Women Gaze at the Precious Thing Their Souls Are Set On," Perceptions of Pregnancy from the Seventeenth to the Twentieth Century. Eds. Jennifer Evans and Ciara Meehan. London: Palgrave Macmillan, 2017. 133-159.

Rüff, Jakob. The expert midwife, or An excellent and most necessary treatise of the generation and birth of man. London, Printed by E. G[riffin] for S. B[urton] and are to be sold by Thomas Alchorn at the signe of the Greene Dragon in Saint Pauls church-yard, 1637. ProQuest, https://search.proquest.com/docview/ 2240895481 ? accountid $=10792$

Schmalenberger, Sarah. "Hearing the Other in The Masque of Blackness." Blackness in Opera. Ed. Naomi André, Karen M. Bryan and Eric Saylor. Urbana: University of Illinois Press, 2012. 32-54.

Sharp, Jane. The Midwives Book, or The Whole Art of Midwifry Discovered. London, printed for Simon Miller, at the Star at the Wet End of St Paul's, 1671. ProQuest, https://search.proquest.com/docview/2240903191?accountid=10792

Sullivan, Mary. Court Masques of James I: Their Influence on Shakespeare and the Public Theatres. PhD Thesis, University of Nebraska, 1913, chapter 1.

Thiel, Sara B.T. "Performing Blackface Pregnancy at the Stuart Court: The Masque of Blackness and Love's Mistress, or the Queen's Masque." Renaissance Drama 45.2 (2017): 211-236.

Vaughan, Virginia Mason. Performing Blackness on English Stages, 1500-1800. Cambridge: Cambridge University Press, 2005.

Vincent, [no first name]. "Masque of Blackness 7: Letter, Vincent to Benson, 10 Jan. 1605." The Cambridge Edition of the Works of Ben Jonson Online. Ed. Martin Butler, David M. Bevington, Karen Britland, Ian Donaldson, David L. Gants, and Eugene Giddens. Cambridge: Cambridge University Press, 2014. http://universitypublishingonline.org/cambridge/benjonson/ 